\title{
The Effectiveness of Symbols: \\ Psychogeographic Explorations of the Body
}

Michelle Williams Gamaker

A performance lecture by Michelle Williams Gamaker

with Violeta Paez-Armando, Rosie Dowd-Smyth, Nina Kuttler, and Hazal Kaygusuz ${ }^{\text {I }}$

In The Effectiveness of Symbols (1972), Claude Lévi-Strauss recounts the experience of a woman undergoing a difficult childbirth. A shaman is called upon to alleviate the "blockage" and she receives a cure by song. The song (an object in itself) represents a voyage through the body's interior geography, in which the shaman encounters fantastic beasts, a way to visualize and personify pain, and thus offer the pregnant woman a way to "see" her pain. This is where the power of objects, the use of theatrical devices and dramatic representation comes in, by highlighting the materiality of the body. This article will explore the idea of healing through theatrical modes, by telling stories and turning the notion of abstract possibilities into concrete action to relate the symbolic and material approaches to effecting "cures."

Michelle Williams Gamaker is dressed head to toe in white thermals. She sits alone on a medical table, with three apples and balls of yarn placed upon it. In front of her is a tiered wooden seating stand - she is in a medical theater packed full of spectators. Hazal Kaygusuz stands further back holding a camera. She takes photos of the scene.

\footnotetext{
Michelle:

In his book "Madness and Civilization" French philosopher and historian Michel Foucault noted that French doctors during the 1700s identified the key role imagination played in effecting cures; he highlights the significance of symbolism in treatments.
} 

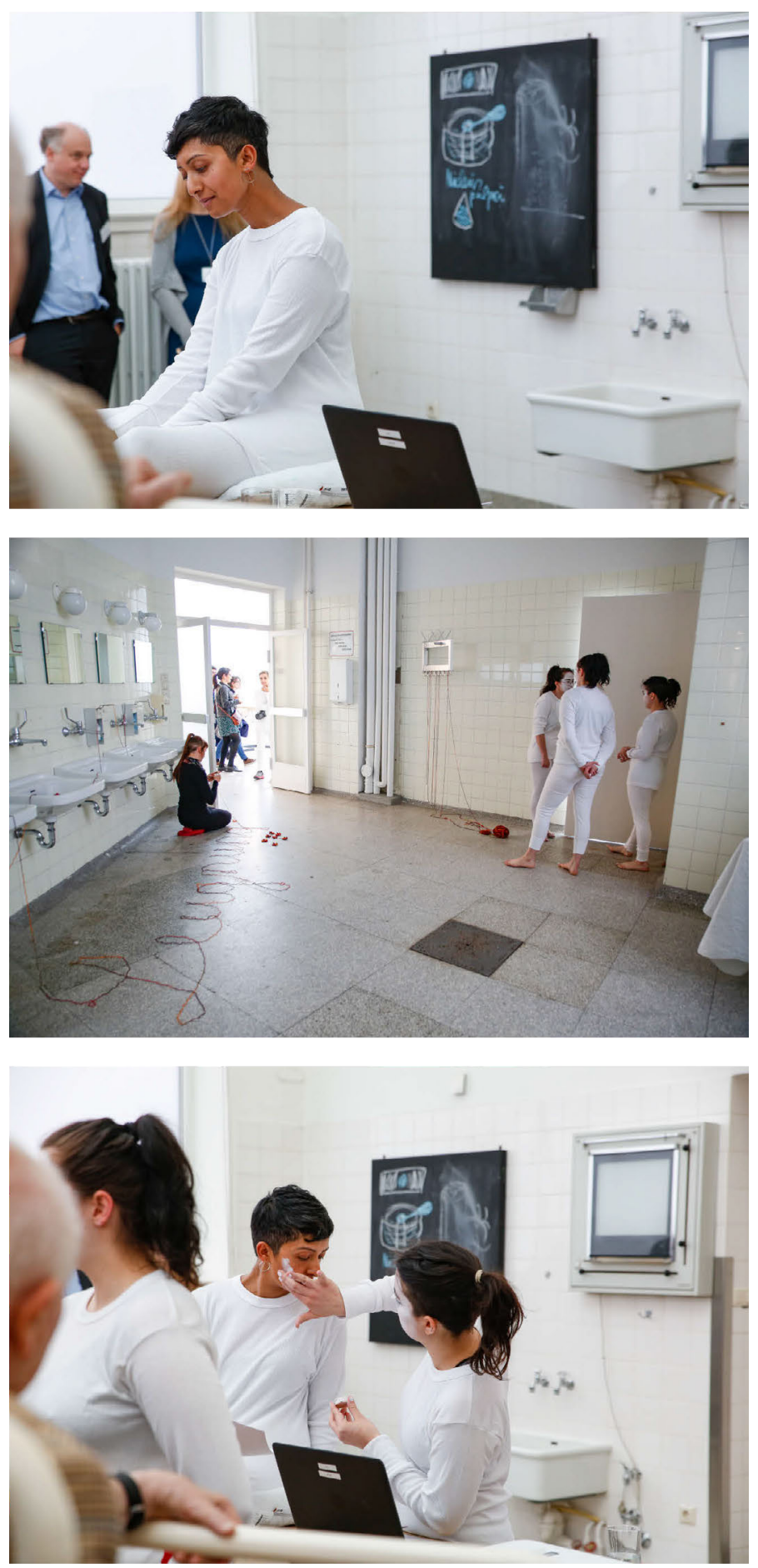
By the late 1700s, however, rather than being widely advocated as a means of cure, "the unity of symbols begins to break down and the techniques lose their total significance" (Foucault 1961 [2001]: 168).

Violeta Paez-Armando, Rosie Dowd-Smyth, and Nina Kuttler enter.

Each wears white thermals and their faces are painted white. They stand in front of Michelle. Each takes an apple from the table and looks directly at the audience. Together the five women look like patients for some nameless institution.

Violeta begins to paint Michelle's face white, while she continues to read:

Foucault writes: "If an illusion can appear as true as perception, perception in turn can become the visible, unchallengeable truth of illusion. Such is the first step to the cure by 'theatrical representation':

to integrate the unreality of the image into perceived truth, without the latter seeming to contradict or even contest the former" (ibid.: 178).

\section{A projector shows the words THEATRICAL REPRESENTATION}

Michelle:

Foucault cites an example that suggests that theatricality can be effective in healing, which can be considered a cure by "theatrical representation."

Foucault describes the case of a man who thought he was dead and thus did not feel the need to eat and in doing so began to die of starvation. Those attending him painted their faces white and dressed themselves in ghostly attire. A table was placed at the foot of the patient's bed and they began to eat and drink, much to the surprise of the patient. When questioned by him they replied that "dead people eat just as much as living ones" (ibid.: 179). The patient was able to integrate this illusion as a fact, and began to eat again. There are also comparable examples of artists operating on the border between art, therapy, and theatrical representation, and this talk will explore Brazilian artist Lygia Clark. 
Violeta, Rosie, and Nina each take a ball of wool. They slowly begin to unravel the yarn, tying one end to Michelle's ankles and the other to members of the audience. They repeat this action while the lecture continues.

\begin{abstract}
Michelle:
Lygia Clark's transformation in the mid-1970s from artist to practitioner of experimental psychotherapy cannot easily be compared with other artists. She began by devising a new role for the art spectator by instigating an active rather than passive subjectivity, passing her agency as artist to the spectator and encouraging them to take control of the creative process.

Upon returning to Brazil from Paris in 1976, Clark established a therapeutic practice in Copacabana. There her clients mainly comprised former art spectators and professional associates undoubtedly familiar with her work, as well as prostitutes working in the area. There were also clients with neuroses and more serious psychotic disorders who attended individual treatments. Following psychoanalytic practice to undergo psychoanalysis as an analysand, Clark underwent analysis with Pierre Fédida (who had been a student of Gilles Deleuze and was influenced by Jacques Lacan's work). Her writing references the work of Melanie Klein, D.W. Winnicott, and Wilfred Bion. Like these analysts, Clark helped her clients return from isolated, non-engaging states to a world in which they could utilize their creative capacity.
\end{abstract}

The trio continues to link Michelle to individuals sitting near the front and those at the back of the tiered seating by tying thread to their wrists.

Michelle:

Clark's Baba Antropofágica, meaning "Cannibalistic Drool" (1973), was an example of what she referred to as "propositions." In "Baba," a figure lies recumbent on the floor with eyes closed. Working with a group called "Corpo Coletivo," the "Collective Body" lean over and encircle their subject and begin pulling continuously from a reel of thread that is concealed in their mouths. As they pull on the thread it falls on the face and body of the figure. 
A red and pink cobweb has formed.

Michelle:

The threads are coated with saliva and in the act of regurgitation it seems to parch the participants mouths. A hot, sticky thread clings like a cobweb that slowly forms a multi-colored crystalline cocoon that smothers and protects the body.

In the transient nature of the material the web appears both strong and frail. After the thread is cast, the group lays their hands over the shrouded figure and begins, randomly, to remove tufts of cotton.

This performance is heavily symbolic: each of these small acts constitutes a metaphor. Art writer Guy Brett discusses "the chain of metaphors" which unravels in "Baba." The cotton thread, as saliva is drawn from the interior of the body, stands for the viscera as a symbol of psychic being. Brett goes on to link the thread to a "lifeline" (2004: 40). The mouth represents a transitional space: interior but also able to expel air and voice into the space outside the body.

Violeta, Rosie, and Nina begin to cough, as if trying to remove something from the back of your throat. They continue connecting yarn to the audience members.

\footnotetext{
This pulling up of the innards brings about a catharsis of the very being of an individual, in which the participant is in an open and seemingly vulnerable position. That vulnerability can be compared to the feeling of a hair at the back of the mouth, an intrusion, a foreign article that is in the wrong place. Here the body reacts in very different ways to thought, its natural instinct is to repel the intrusion, with a spontaneous gagging or coughing action.
}

Violeta begins to paint black lines on Michelle's face, as if her face is covered in fur. Nina and Rosie continue to connect thread to the audience.

Michelle:
In The Effectiveness of Symbols (1972), Claude Lévi-Strauss recounts
the experience of a woman undergoing a difficult childbirth by ex-
ploring a Cuna ${ }^{3}$ song, which details a shaman who is called upon 
The Effectiveness of Symbols
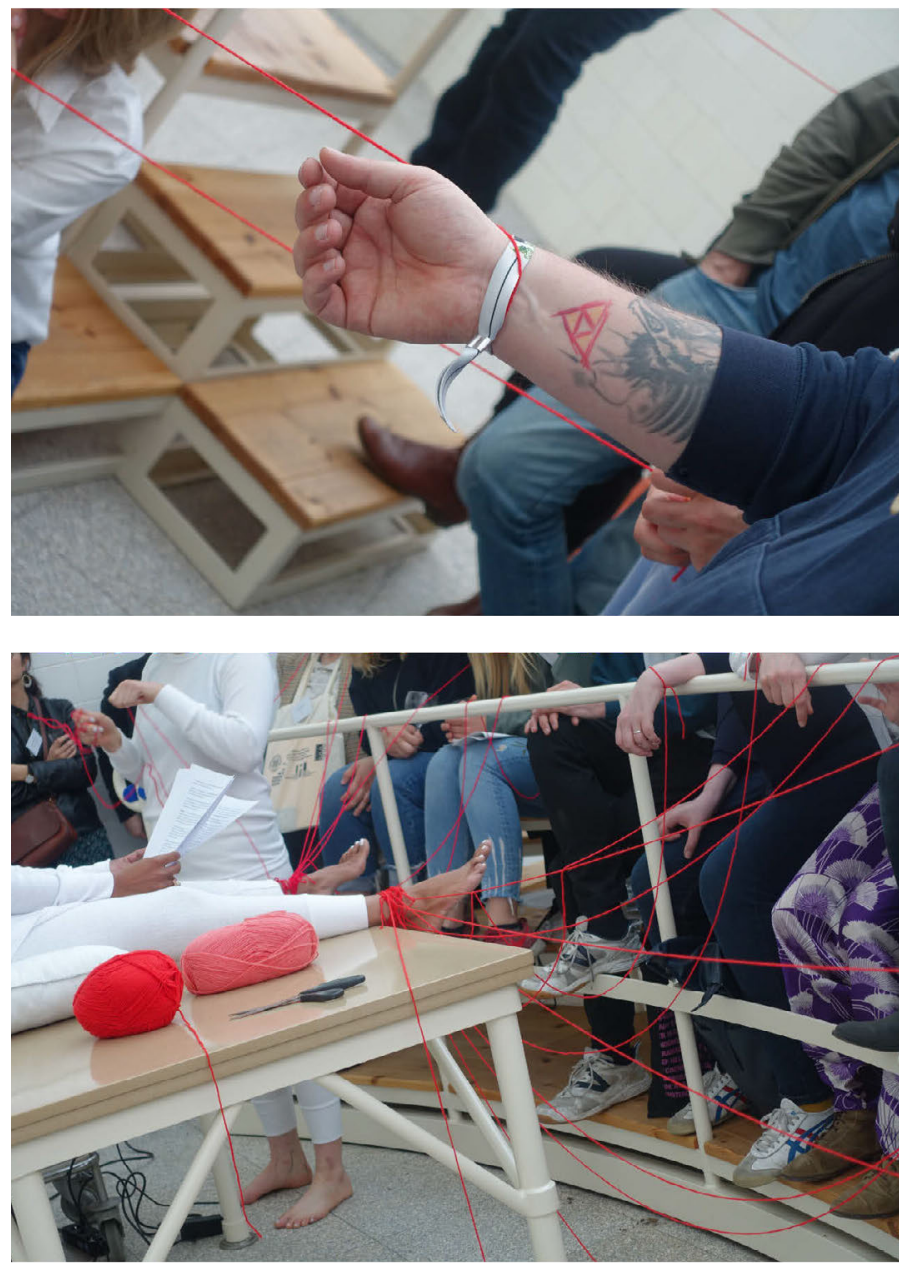
to alleviate the "blockage." The woman in labor receives her cure by song. The song represents a voyage through the body's interior geography, upon which the shaman encounters fantastic beasts that, according to the native informant, "increase the diseases of the laboring woman" (Lévi-Strauss 1972: 195) and populate the ambiguous geographic interpretation of her body.

Lévi-Strauss explains that these creatures, who are actually the product of visualization, personify pain, and in this sense give the pregnant woman a way to see her situation. This is where the power of objects comes in.

The shaman [nelegan] must defeat these animals and "overcome other obstacles, this time material: fibers, loose threads, fastened threads, successive curtains" (ibid.: 196) of multitudinous colors. These fibers must be cut back, and the shaman calls for assistance from the Lords of the wood-boring insects: the wood-boring beetles, longhorn beetles, bark beetles, and weevils, and the metallic flat-headed borers.

And the Lords of the burrowing animals: moles, great gerbil, gopher, groundhog, the hoary marmot to cut at the uterine tissues (ibid.: 196). He notes that these supernatural assistants form part of a coherent system in which the pregnant woman and her community believe. They do not have to question the existence of these mythical protagonists, and Lévi-Strauss observes that the cure consists of "making explicit a situation originally existing on an emotional level and in rendering acceptable to the mind the pains which the body refuses to tolerate" (ibid.: 197).

He locates this as a "relationship between symbol and thing symbolized ... between sign and meaning" (ibid.: 198) suggesting the shaman gives the woman a language to formulate inexpressible psychic states without difficulty. The introduction of a language of signs brings a coherent logic to the mind and body of the woman, which Lévi-Strauss terms a re-organization in her physiological process (ibid.).

It is in this conjunction of functions where objects are outer and become inner, that we can see the analogy between shamanism and the aspects of Clark's practice where art and therapy meet. 
Clark's therapy is similar to the shaman's psycho-geographic exploration of the body in that she articulates through the body as a tool for self-expression that which the patient has no words to describe adequately. She sought to reintegrate the body image with the self, recalling Lévi-Strauss's reorganization of a physiological process. Her Objetos Relacionais [Relational Object], cheap, readily accessible materials are symbolic proxies (like the spirit agents in the Cuna song) that come to personify the subject's pain and anxieties. These shamanistic disciplines allow the patient to clarify and visualize the healing process. Confusion is abated: anxiety and helplessness are given a visualization that allows the patient to comprehend it.

Once given an identity and substance - or, to put it another way, once the abstract nature of the illness has been embodied or objectified - the patient is more able to combat it. It allows the patient to direct his or her self-healing at the source of the disturbance. This extends to the possibility that one need not be ill to experience the beneficial effect of objects.

In The Effectiveness of Symbols, Claude Lévi-Strauss offers an example from a study by Swiss psychoanalyst Marguerite A. Sechehaye, who invented the method that became known as "symbolic realization," for the treatment of schizophrenics from 1947. Her research found that speech, regardless of its rich symbolism, could not go beyond the conscious and that "she could reach buried complexes only through acts" (ibid.: 200).

Lévi-Strauss suggests that the symbolism of these acts is a language the therapist uses, which allows a dialogue "not through the spoken word, but by concrete actions ... to carry their message directly to the unconscious" (ibid.: 200). In considering the physicality of Sechehaye's acts he returns to the idea of manipulation. Whether physical or psychological, he states "the manipulation must be carried out through symbols" (ibid.).

Violeta, Rosie, and Nina continue to cough, as if trying to remove something from the back of their throats.

This time they produce a small piece of wool wrapped like a worm from your mouth. It is covered in saliva. They hand it to individuals in the audience. 
In the essay The Sorcerer and his Magic (1949), Lévi-Strauss wrote on the basis of Franz Boas's observations of the Nambicuara Indians in the savannas of central Brazil and the Kwakiutl Indians of Vancouver, Canada. He gives an account of a man named Quesalid. Unlike the majority of his community, Quesalid did not believe in the powers of sorcery but learned the techniques of the shamans through his inquisitive nature. Initially he set out to expose shamanism for its fraudulent use of trickery but found that he too was equally if not more effective in instigating cures. His key skill (used by the shamanistic schools of the northwest coast of Brazil) was the practice of hiding a worm or a tuft of down inside a corner of the mouth to be produced, covered in blood, at the appropriate moment. Biting the tongue or making his gums bleed achieved this. The object represents a tangible signifier of illness and it is presented to the "patient and the onlookers as the pathological foreign body extracted as a result of his sucking and manipulations" (ibid.: 175).

This technique, utilizing both deception and effective healing, can be compared to Clark's techniques. She referred to her techniques as "gross tricks" that form part of her repertoire of phenomenal tricks to enable the client to understand the abstract nature of their problem. In The Relational Object (1980) Clark describes an instance quite comparable to that of the shaman in Lévi-Strauss's book. It concerns a patient who imagined a stiffened fetus inside his stomach, while neither Clark nor her patient knew what this could mean. She writes:

"He had an enormous belly. I lay upon it, belly upon belly for a long time and I said: "You are going to pass into my belly, you are going to pass into my belly." Then I sucked his belly button a great deal and he went away" (Clark 1983: 2).

Clark employs this somewhat crude, intuitive strategy as a means toward changing the status of a perceived foreign object within the body. Her clinical notes record:

"It was necessary for this gross trick to take place for me to realize that it was his feminine side made explicit as a complement to the masculine side, and stroking his belly affectionately and [with] my hand I said it was going to be integrated, not to be put on the outside, but to integrate it. It was integrated in time" (ibid.: 2). 
Violeta, Rosie, and Nina begin to cut the threads from Michelle.

Michelle:

Rather than attempting to banish the unwanted object of the swelling outside of the psyche (and consequently the body), Clark wanted the object to integrate into the subject's body. This integration implied that her client "dissolved" the foreign object or the concept of its presence into himself. She intervenes by using an approach at once concrete and abstract - concrete in its bodily contact and abstract because no representation is being made. Here, Clark takes the place of her Objetos Relacionais (lying on top of his stomach) and by employing the gross trick of sucking out the psychosomatically induced foreign object (from his stomach). This device, like the shaman's bloody worm, allowed the subject and Clark to grasp the root of the problem. The operative words in the text are "for me to realize," implying that it was through an empathic understanding of the patient that Clark, as a healer, could resolve the disturbance.

In considering the physicality of Sechehaye's acts, Lévi-Strauss returns to the idea of manipulation. Whether physical or psychological, he states "the manipulation must be carried out through symbols" (Lévi-Strauss 1972: 200).

He compares the acts (gestures) of Sechehaye that "reverberate in the unconscious mind of the schizophrenic just as the representations evoked by the shaman bring about modification in the organic functions of the woman in childbirth [the patient]" (ibid.: 200).

Lévi-Strauss discusses the duality of the patient and healer dyad, concluding that the therapist "acts" and the patient "produces the myth," while the shaman produces the myth and the patient performs the actions. These actions manifest themselves inside the body and usually end with good health or, in our example, with the birth of a child. Lévi-Strauss further suggests that "when it [the cure] deals directly with the unhealthy organ, it is too grossly concrete (generally, pure deceit) to be granted intrinsic value" (ibid.: 191).

This implies that poetic narrative and visual imagery are psychological representations that specifically attack the physical manifestations of psychological disturbances by weakening their rigidity. 

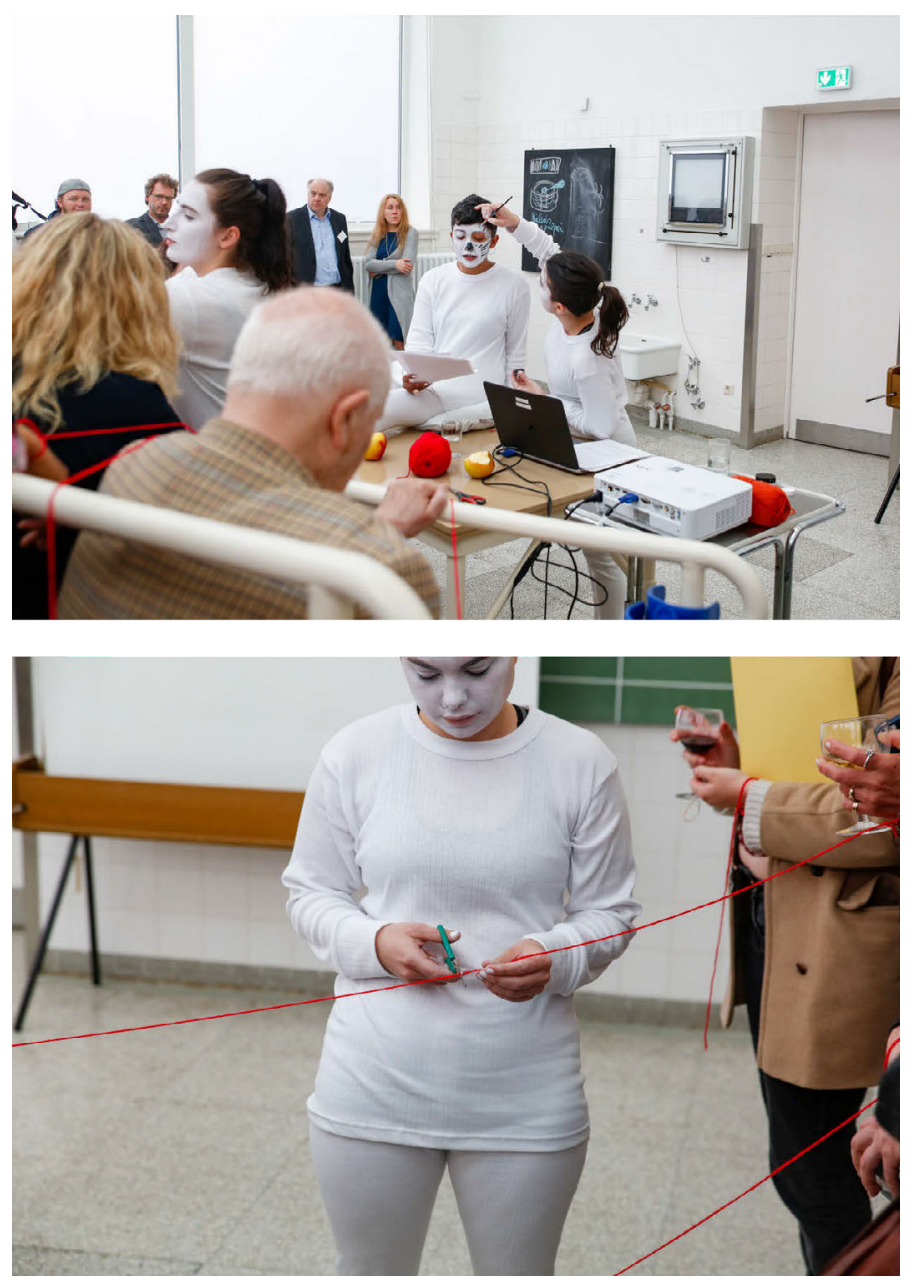
Michelle delves into the crotch of her thermals and produces an apple, which she begins to eat, while continuing to read:

Sechehaye also found that objects held great value in allowing her schizophrenic patients to actualize a fantasy object. In her in-depth study The Poetics of Psychoanalysis: In the Wake of Klein (2005), Mary Jacobus refers to Winnicott's use of Sechehaye's work, in which she produced an object, in this case an apple, at the right moment. Winnicott suggests:

"The important thing was that the patient was able to create an object, and Sechehaye did no more than enable the object to take the apple-shape, so that the girl had created an actual part of the world, an apple" (Jacobus 2005: 115).

Clark, like Sechehaye and the more abstract techniques of shamanism, utilized the potential of objects to enable her clients to access emotional knowledge from their bodies. The Objetos Relacionais, over the course of several sessions, became familiar forms with which her clients could identify.

Through this process of interaction and identification with objects, Clark provided the client with the opportunity to make conclusions about themselves, whether poetic, imagined, or real. These conclusions not only connected her participants to their personal relationships but also enabled them to locate themselves in the world. Clark's contribution to her clients' attempts to develop a creative strategy to draw conclusions about themselves offered an experience as a type of language to help formulate inexpressible psychic states.

By the end of the talk, the threads should all be cut.

This signals the end. 

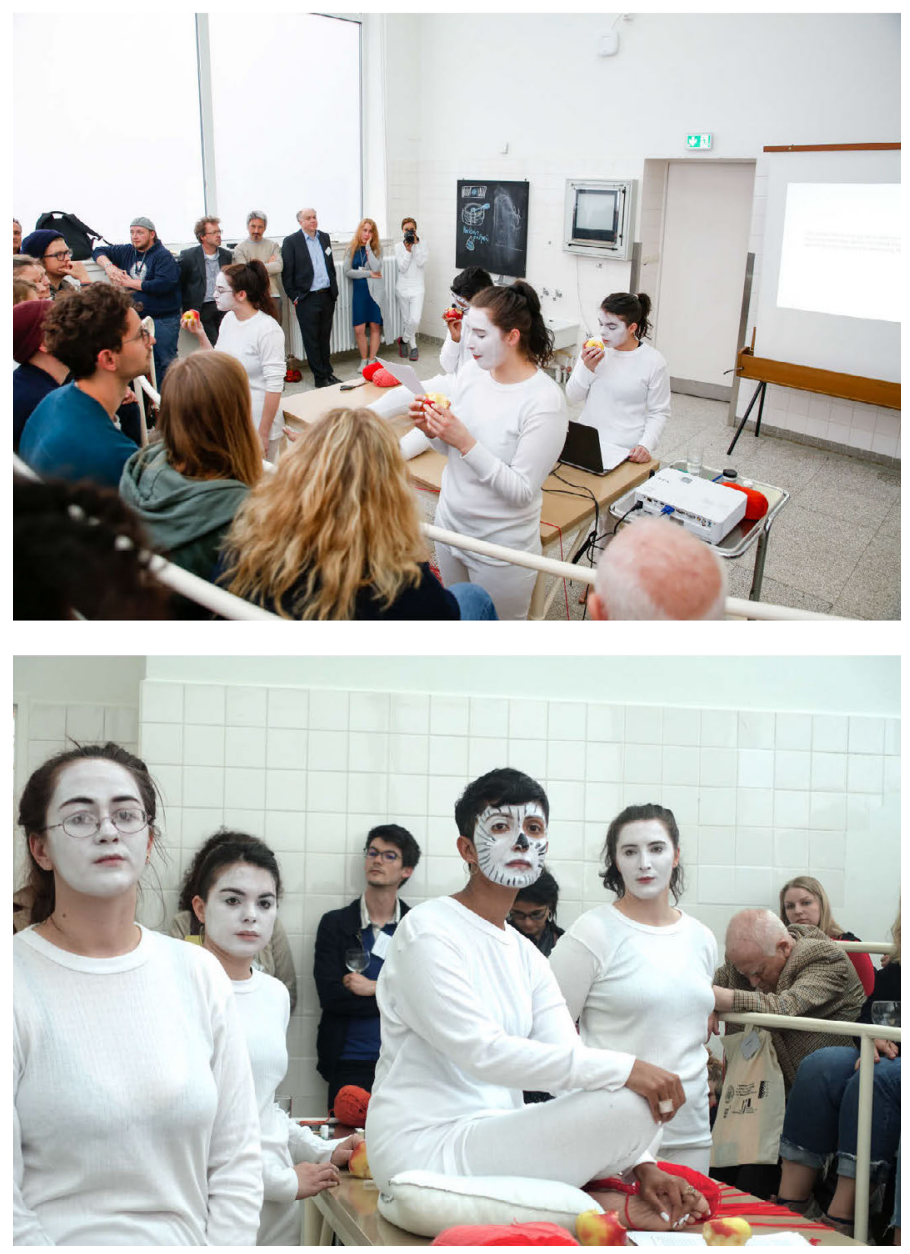


\section{Notes}

\section{1}

Presented at the international conference on

"Material Cultures of Psychiatry" at the Museum for Medical History/Institute for History and Ethics of Medicine at the University Medical Center Hamburg-Eppendorf in cooperation with the Luxembourg Centre for Contemporary and Digital History. The photos of the performance were taken at the conference.

\section{2}

Clark used the term "propositions" broadly to describe individual and collective encounters with materials and objects that she termed "Relational Objects" [Objetos Relacionais]. These were former sculptures that evolved into therapeutic tools in her experimental psychotherapeutic practice.

\section{3}

The Cuna are indigenous people of Panama and Colombia.

\section{Bibliography}

Clark, Lygia (1983): Letter to Guy Brett, Rio de Janeiro, Brazil, October I4, I983, courtesy of the World of Lygia Clark Foundation, Brazil, 2009. Brett, Guy (2004): Carnival of Perception: Selected Writings on Art, London: Institute of International Visual Arts.

Foucault, Michel (2001 [1961]): Madness and Civilization: A History of Insanity in the Age of Reason, transl. from the French by Richard Howard, Abingdon: Routledge.

Jacobus, Mary (2005): The Poetics of Psychoanalysis: In the Wake of Klein, Oxford: Oxford University Press.

Lévi-Strauss, Claude (1972): Structural Anthropology I, transl. from the French by Claire Jacobson and Brooke Grundfest Schoepf, vol. 1, London: Penguin University Books. 